\title{
Effects of the Curing Process on the Residual Stress in Solar Cell Module
}

DOI: $10.15255 /$ KUI.2015.048 KUI-11/2016

Original scientific paper Received December 3, 2015 Accepted January 28, 2016

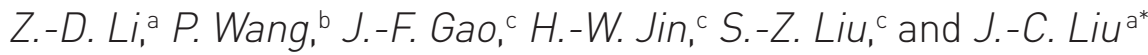 \\ a School of Materials Science and Engineering, Tianjin Polytechnic University, \\ 300387 Tianjin, P.R. China \\ ${ }^{b}$ Auditing Department, Tianjin Polytechnic University, 300387 Tianjin, P.R. China \\ c The $18^{\text {th }}$ Research Institute, China Electronics Technology Group Corporation, \\ 300381 Tianjin, P.R. China
}

\begin{abstract}
\| Abstract
Panels using solar power require high reliability, and the residual stress in the solar panel has an important effect on its reliability and lifetime. The finite element method was adopted to simulate the impacts of the rectangular solar panel encapsulation process parameters, such as the elastic modulus, the thickness of adhesive, and the curing temperature on the residual stress in the solar cell module. The results show that the residual stress in the solar cell module increases linearly with the increase in these three factors. The residual strain is consistent with that of the stress. The generation mechanism and distribution evolution of stress are discussed in detail. Both the thickness and the elastic modulus of the silicone rubber have significant impact on the residual stress. However, the influence of the curing temperature is less observable.
\end{abstract}

\section{$\|$ Keywords}

Solar cell module, curing process, residual stress, finite element method, elastic modulus

\section{Introduction}

Solar cells can convert solar energy into electrical energy using the photoelectric effect, and have been widely used in the aerospace, industrial and civil fields. The solar cell's layered configuration mainly includes photoelectric semiconductor material, anti-radiation coverglass and adhesive. ${ }^{1}$ During the manufacturing and service processes of the solar cell module, the residual stress proceeds into the solar cell module because of the mismatch of the materials' thermal expansion coefficients, and the curing process of the adhesive, which may result in cracking, and even detachment of the solar cell module. ${ }^{2-4}$ The effect of the adhesive on the residual stress in the solar cell module has yet to be studied. However, residual stress is difficult to measure by the experimental method.

Due to the high cost of the actual experiment, the finite element method has been increasingly used to detect the state of solar cell module at its encapsulation and service process. ${ }^{5}$ Zhang et al. found that the tensile strength of solar cell sample at room temperature decreases with the increase in the thermal cycling times. The corresponding pattern of the fracture transformed from mixed failure to cohesive failure. ${ }^{6-7}$ Brand et al. investigated the film stresses that developed in the polymer films and the metal electrodes of the organic solar cells, and found that the compressive stresses in the electrodes lead to a buckling instability, resulting in undulating electrode surface topography. ${ }^{8}$ Yooh et al. investigated the effects of the thicknesses of the silicon layer and the aluminium layer of a crystalline silicon solar cell on the bow with the non-di-

\footnotetext{
* Corresponding author: Dr Juncheng Liu

e-mail: jchliu@tjpu.edu.cn
}

mensional deformation ratio. The results revealed that the bowing degree increased with the decrease in the silicon layer thickness and increase in the aluminium layer thickness. ${ }^{9}$ The longer life and greater reliability of satellites has put forward higher requirements for solar cells; both the property and the amount of adhesive are important factors affecting the performance of modern satellites. ${ }^{10-12}$

In order to investigate the residual stress of the solar cell module after encapsulation, the distribution and evolution of the residual stress will be simulated during its encapsulation process with the finite element method, and the impacts of the encapsulation process parameters, such as the elastic modulus, the thickness of adhesive, and the curing temperature on the residual stress will be investigated.

\section{Simulation model and boundary conditions}

The schematic view of the simulation model and the coordinate system are shown in Fig. 1. The solar cell module contains the germanium solar cell, the coverglass, and the adhesive. The adhesive here is liquid silicone rubber. The actual size of the solar cell module is $60 \mathrm{~mm} \times 40 \mathrm{~mm} \times 0.645 \mathrm{~mm}$. Because the research object is symmetric, the simulation model is a quarter of the actual object. Some displacement constraints need to be added: the nodes on the face OAB have a fixed displacement in $x$ direction; the nodes on the face OBC have a fixed displacement in $y$ direction; the nodes on the face OAC have a fixed displacement in $z$ direction. The material's parameters of the simulation involved are provided by 
related articles and some research institutions, as shown in Table $1 .{ }^{4}$

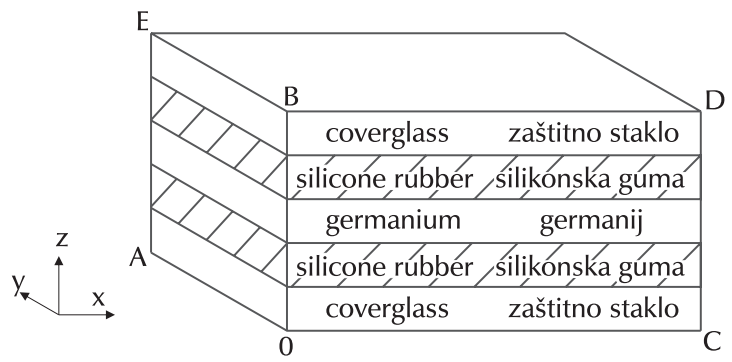

Fig. 1 - Sample pattern of element solar cell module structure Slika 1 - Struktura elementa modula solarne ćelije

Table 1 - Performance parameters of the materials making the element solar cell module structure

Tablica 1 - Svojstva materijala koji sačinjavaju strukturu elementa modula solarne ćelije

\begin{tabular}{|c|c|c|c|}
\hline & $\begin{array}{l}\text { Coverglass } \\
\text { Zaštitno } \\
\text { staklo }\end{array}$ & $\begin{array}{l}\text { Silicone } \\
\text { rubber } \\
\text { Silikonska } \\
\text { guma }\end{array}$ & $\begin{array}{c}\text { Germanium } \\
\text { Germanij }\end{array}$ \\
\hline $\begin{array}{l}\text { thickness / } \mu \mathrm{m} \\
\text { debljina / } \mu \mathrm{m}\end{array}$ & 120 & 115 & 175 \\
\hline $\begin{array}{l}\text { elastic modulus / GPa } \\
\text { modul elastičnosti / GPa }\end{array}$ & 75.56 & 0.0028 & 103 \\
\hline $\begin{array}{l}\text { Poisson's ratio } \\
\text { Poissonov omjer }\end{array}$ & 0.209 & 0.47 & 0.26 \\
\hline $\begin{array}{l}\text { coefficient of thermal } \\
\text { expansion } /{ }^{\circ} \mathrm{C}^{-1} \\
\text { koeficijent toplinskog } \\
\text { rastezanja } /{ }^{\circ} \mathrm{C}^{-1}\end{array}$ & $7.058 \cdot 10^{-6}$ & $2 \cdot 10^{-4}$ & $6.1 \cdot 10^{-6}$ \\
\hline $\begin{array}{l}\text { thermal conductivity/ } \\
W(\mathrm{~m} \cdot \mathrm{K})^{-1} \\
\text { toplinska provodljivost/ } \\
\mathrm{W}(\mathrm{m} \cdot \mathrm{K})^{-1}\end{array}$ & 1.38 & 0.2 & 64 \\
\hline
\end{tabular}

The encapsulation process includes the following steps: All parts are bonded together, subsequently the solar cell module is heated at $60{ }^{\circ} \mathrm{C}$ for 4 hours in an oven. This simulation work involves the curing process of the silicone rubber. In fact, the curing process includes many complicated physical and chemical changes, such as the solidification process of the liquid phase. ${ }^{13}$ When the reaction of the polyfunctional monomers proceeds for a certain time, the viscosity increases continuously, and a gel-form polymer appears; the degree of the reaction is called the gel point. The gel point can be calculated by comparing the storage modulus and loss modulus. ${ }^{14}$ The required time for the silicone rubber's viscosity and storage modulus to finally reach a stable value is called curing time. This process involves a certain degree of deformation, the change of the silicone rubber elastic modulus with the chemical transformation, the thermal stress caused by the curing temperature, all of which become the major source of the residual stress produced in the solar cell module. CAE software transforms the engineering problems into different units of a discrete computational model for obtaining a comprehensive outcome. Currently, all the mainstream CAE softwares are difficult to simulate this process perfectly. Therefore, the simulation requires a certain degree of simplification in order to achieve an accurate result. In the actual experiment, a $5 \%$ volume expansion occurred and approximately $90 \%$ of the deformation was accomplished during the first twenty minutes. The deformation caused by the mismatch of all parts materials results in the residual stress in the solar cell module through the curing process of the silicone rubber.

The initial state of the silicone rubber is a viscoelastic body from the mechanical point of view. After the curing process, the silicone rubber exhibits elastomeric features. The silicon rubber follows the law of elastic deformation and Hooke's law throughout the curing process. Therefore, the strain is basically identical to the residual stress in the solar cell module. Meanwhile, it is assumed that the elastic modulus of the silicone rubber shows a uniform linear variation, from a very low modulus to a normal modulus (2.8 MPa).

The research object is regarded as an elastomer. After the curing process, the deformation of the solar cell module and the change of elastic modulus cause the residual stress. ${ }^{15}$ Displacement of the internal nodes occurred during the curing process along the $x, y$, and $z$ directions, respectively. This process involves a series of stress-strain relationships; $u, v$ and $w$ are the relative displacement components in each part of the solar cell module, which are a function of the coordinates of the nodes. The relationship is given as:

$$
\begin{aligned}
& u=u(x, y, z) \\
& v=v(x, y, z) \\
& v=v(x, y, z)
\end{aligned}
$$

During the deformation of the solar cell module, the three longitudinal strain components and the three shear strain components are $\varepsilon_{x,} \varepsilon_{y \prime} \varepsilon_{z \prime}, \gamma_{x y}, \gamma_{y z \prime} \gamma_{x z}$. Meanwhile, the normal stress component and the shear stress component of each node are $\sigma_{x \prime} \sigma_{y,} \sigma_{z \prime} \sigma_{x y \prime} \sigma_{y z \prime} \sigma_{z x}$. Their definitions are given as:

$$
\begin{array}{ll}
\varepsilon_{x}=\frac{\partial u}{\partial x}, & \gamma_{x y}=\gamma_{y x}=\frac{\partial u}{\partial y}+\frac{\partial v}{\partial x} \\
\varepsilon_{y}=\frac{\partial v}{\partial y}, & \gamma_{y z}=\gamma_{z y}=\frac{\partial v}{\partial z}+\frac{\partial w}{\partial y} \\
\varepsilon_{z}=\frac{\partial w}{\partial z}, & \gamma_{z x}=\gamma_{x z}=\frac{\partial w}{\partial x}+\frac{\partial u}{\partial z}
\end{array}
$$

According to elastic mechanics, the equations of the stressstrain are given as:

$$
\varepsilon_{x}=\frac{1}{E}\left[\sigma_{x}-v\left(\sigma_{y}+\sigma_{z}\right)\right], \gamma_{x y}=\frac{\sigma_{x y}}{G}
$$




$$
\begin{aligned}
& \varepsilon_{y}=\frac{1}{E}\left[\sigma_{y}-v\left(\sigma_{x}+\sigma_{z}\right)\right], \gamma_{y z}=\frac{\sigma_{y z}}{G} \\
& \varepsilon_{z}=\frac{1}{E}\left[\sigma_{z}-v\left(\sigma_{x}+\sigma_{y}\right)\right], \gamma_{z x}=\frac{\sigma_{z x}}{G}
\end{aligned}
$$

where $E$ is the elastic modulus of silicone rubber, $v$ and $G$ denote Poisson's ratio and the shear modulus, respectively. Their relationships are given as follows:

$$
G=\frac{E}{2(1+v)}
$$

Thus, the matrix equation can be obtained from the above formula:

$$
\left[\begin{array}{c}
\sigma_{x} \\
\sigma_{y} \\
\sigma_{z} \\
\sigma_{x y} \\
\sigma_{y z} \\
\sigma_{z x}
\end{array}\right]=\frac{E(1-v)}{(1+v)(1-2 v)}\left[\begin{array}{cccccc}
1 & \frac{v}{1-v} & \frac{v}{1-v} & 0 & 0 & 0 \\
\frac{v}{1-v} & 1 & \frac{v}{1-v} & 0 & 0 & 0 \\
\frac{v}{1-v} & \frac{v}{1-v} & 1 & 0 & 0 & 0 \\
0 & 0 & 0 & \frac{1-2 v}{2(1-v)} & 0 & 0 \\
0 & 0 & 0 & 0 & \frac{1-2 v}{2(1-v)} & 0 \\
0 & 0 & 0 & 0 & 0 & \frac{1-2 v}{2(1-v)}
\end{array}\right]\left[\begin{array}{c}
\varepsilon_{x} \\
\varepsilon_{y} \\
\varepsilon_{z} \\
\gamma_{x y} \\
\gamma_{y z} \\
\gamma_{z x}
\end{array}\right]
$$

The matrix equation can be simplified as follows:

$$
\sigma=E \varepsilon
$$

modulus should affect greatly the residual stresses in these two parts. Here, the silicone rubber elastic modulus takes five values, 0.56 MPa, 1.4 MPa, 2.8 MPa, 5.6 MPa, and 11.4 MPa, respectively.

The effect of the silicon rubber elastic modulus on the stress distribution of the coverglass is shown in Fig. 2. The volume expansion of the silicone rubber after the curing process is obvious. The deformation of the silicone rubber cannot be completely released due to the constraint of the rubber/coverglass interface. The silicone rubber extrusion is mainly concentrated in the module boundary area.

Because of the Poisson's effect, the silicone rubber defor-

Because the silicone rubber comes in direct contact with the germanium solar cell and the coverglass, its elastic

\subsection{Effects of the silicone rubber elastic modulus on the residual stress and strain in solar cell module}
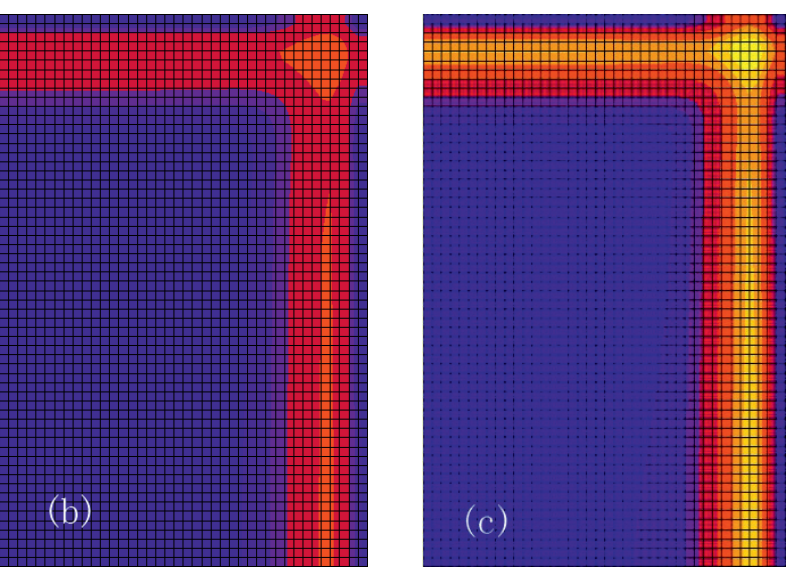

Fig. 2 - Effects of the silicon rubber elastic modulus on the stress in the coverglass: (a) $1.4 \mathrm{MPa}$, (b) $2.8 \mathrm{MPa}$, (c) $5.6 \mathrm{MPa}$

Slika 2 - Utjecaj modula elastičnosti silikonske gume na naprezanje zaštitnog stakla: (a) 1,4 MPa, (b) 2,8 MPa, (c) 5,6 MPa 
$H$

1.181

1.057

$9.324 \cdot 10^{-1}$

$8.082 \cdot 10^{-1}$

$6.840 \cdot 10^{-1}$

$5.598 \cdot 10^{-1}$

$4.356 \cdot 10^{-1}$

$3.114 \cdot 10^{-1}$

$1.872 \cdot 10^{-1}$

$6.295 \cdot 10^{-2}$
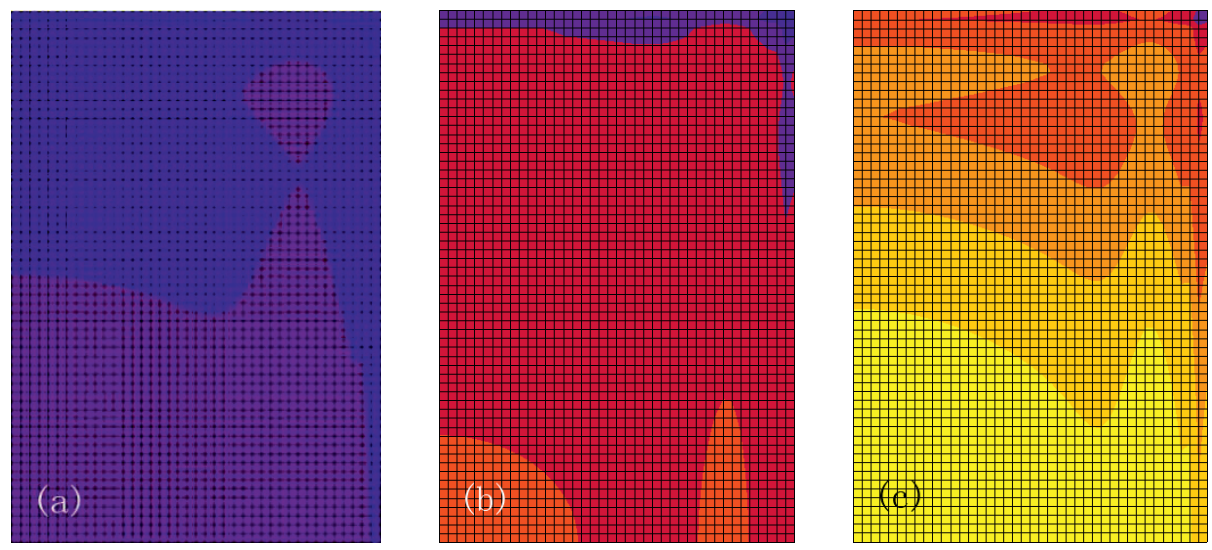

Fig. 3 - Effects of the silicon rubber elastic modulus on the stress in the germanium solar cell: (a) 1.4 MPa, (b) $2.8 \mathrm{MPa}$, (c) $5.6 \mathrm{MPa}$

Slika 3 - Utjecaj elastičnog modula od silikonske gume na naprezanje germanijske solarne ćelije: (a) 1,4 MPa; (b) 2,8 MPa; (c) 5,6 MPa
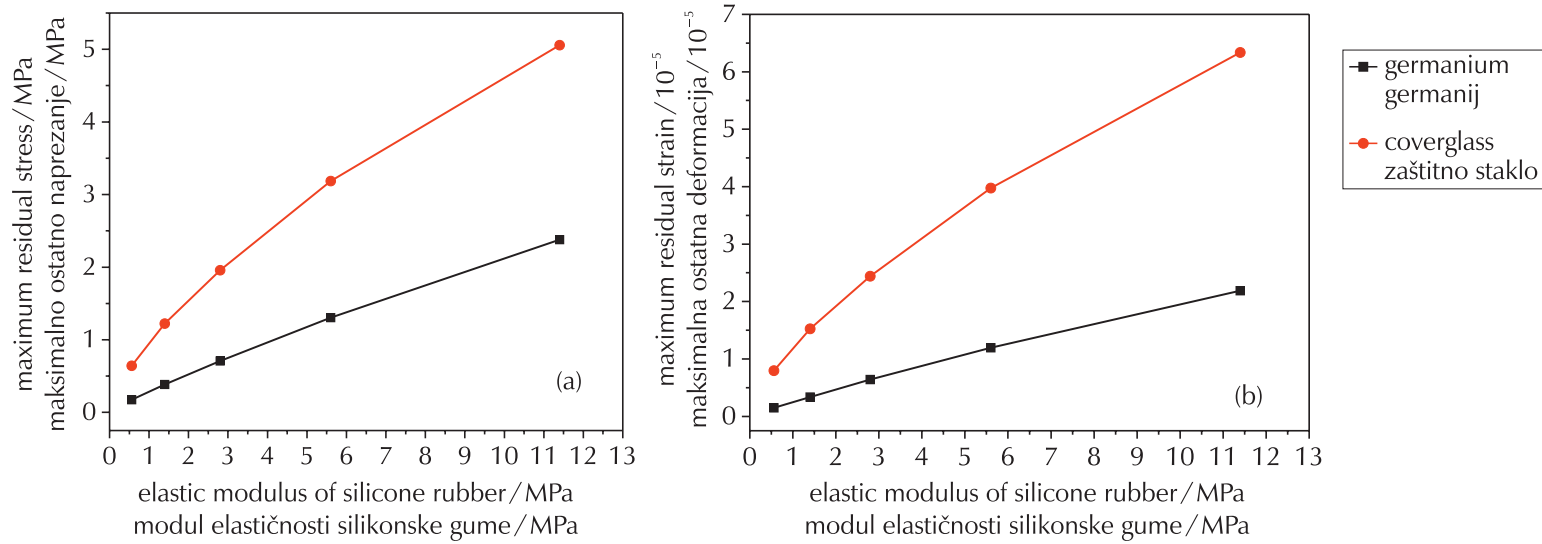

Fig. 4 - Effects of the silicone rubber elastic modulus on the maximum residual stress (a) and maximum residual strain (b) in the solar cell module

Slika 4 - Utjecaj modula elastičnosti silikonske gume na maksimalno ostatno naprezanje (a) i maksimalnu ostatnu deformaciju (b) u modulu solarne ćelije

mation leads to normal stress on the rubber/coverglass interface. At face $\mathrm{BDE}$, the normal stress reaches maximum value due to the stress transfer in the coverglass. Moreover, the residual stress concentrates in the module boundary area, and the maximum value appears in the corner.

The effect of the silicon rubber elastic modulus on the stress distribution of the germanium solar cell is shown in Fig. 3. The germanium solar cell is connected directly with the two parts silicone rubber. After the curing process, the silicone rubber volume expansion causes significant tensile stress at the rubber/germanium interface. In order to meet the equilibrium condition of forces, the fixed position of the germanium solar cell will produce a tensile stress. The maximum stress occurs at the fixed displacement position. Near the corner area of the germanium solar cell appears an obvious stress concentration, which is due to the nor- mal stress caused by the two parts silicone rubber. The normal stresses caused by the two parts silicone rubber are in the opposite direction and the values are approximate, so the strain in the germanium solar cell is smaller than in the coverglass; thus, the normal stress in the germanium solar cell is less than in the coverglass.

With the increase in the elastic modulus, the silicone rubber deformation generated during the curing process remains stable, therefore, it can be observed from equation (11) that the stress will increase in the coverglass and the germanium solar cell.

As can be observed from Figs. 2-3, the distribution of the residual stress in the germanium solar cell is more uniform than that of the coverglass. With different silicone rubber elastic modulus, the maximum stress values in the 
coverglass are always larger those of the germanium solar cell.

The effects of the silicone rubber elastic modulus on the maximum residual stress and maximum residual strain in the coverglass and the germanium solar cell are shown in Fig. 4(a) and Fig. 4(b), respectively. It can be observed that in the coverglass, the residual stress increases obviously with the silicone rubber elastic modulus increase, of which the maximum value increases from 0.642 $\mathrm{MPa}$ to $5.057 \mathrm{MPa}$, about 7.8 times. The strain of coverglass increases from $0.79 \cdot 10^{-5}$ to $6.33 \cdot 10^{-5}$, about 8.0 times when the elastic modulus increases. In the germanium solar cell, the residual stress increases obviously with the silicone rubber elastic modulus increase, of which the maximum value increases from $0.175 \mathrm{MPa}$ to $2.378 \mathrm{MPa}$, about 13.9 times. It can be seen that the strain's change is similar to that of the stress. It increases from $0.14 \cdot 10^{-5}$ to $2.19 \cdot 10^{-5}$, about 15.6 times when the elastic modulus increases.

\subsection{Effects of the silicone rubber thickness on the residual stress and strain in solar cell module}

The residual stress in the solar cell module should become larger with increased thickness of silicone rubber. In order to observe the effects of silicone rubber thickness on the solar cell module clearly, the residual stresses in both parts are calculated with different thicknesses of the silicone rubber. Here, the silicone rubber thickness takes four values, $57.5 \mu \mathrm{m}, 115 \mu \mathrm{m}, 230 \mu \mathrm{m}$, and $460 \mu \mathrm{m}$, respectively.

The effect of the silicone rubber thickness on the stress distribution of the coverglass is shown in Fig. 5. As can be seen, the stress concentrates on the module boundary area, and the maximum value appears in the corner. From the above work, it can be observed that, at face BDE, the stress mainly depended on the normal stress caused by the silicone rubber, so the stress distribution did not change significantly with silicone rubber thickness.
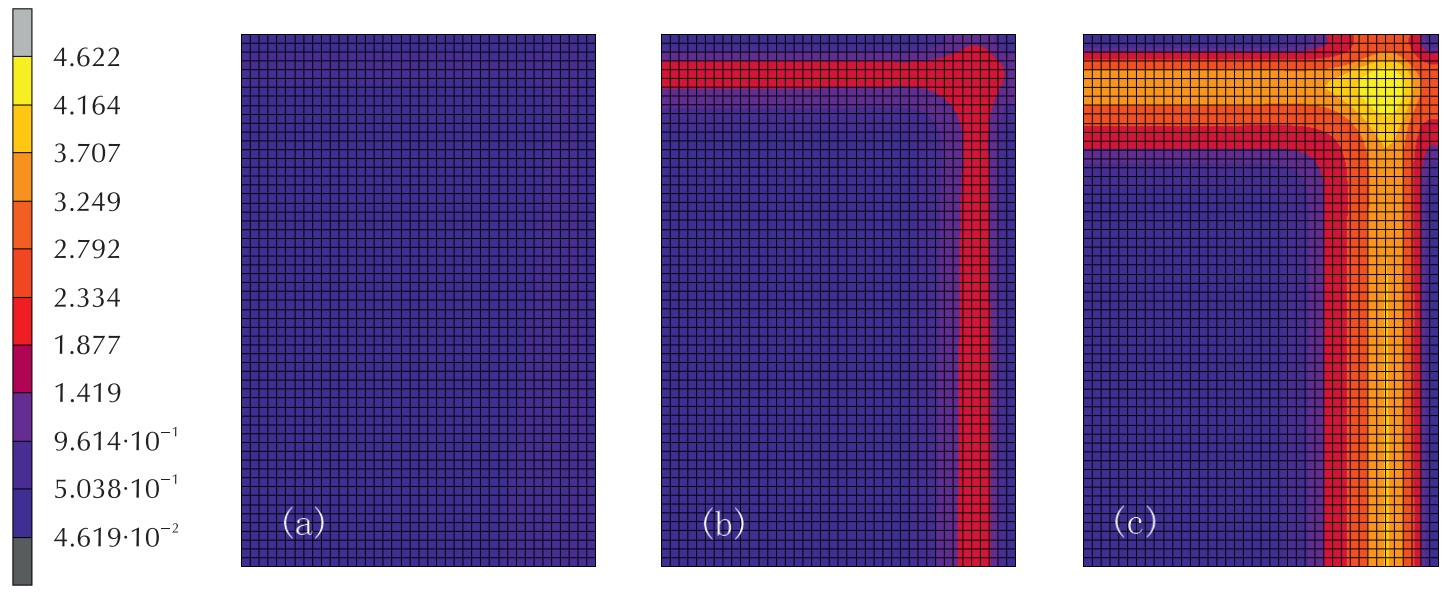

Fig. 5 - Effects of the silicon rubber thickness on the stress in the coverglass: (a) $57.5 \mu \mathrm{m}$, (b) $115 \mu \mathrm{m}$, (c) $230 \mu \mathrm{m}$

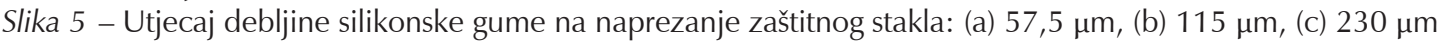
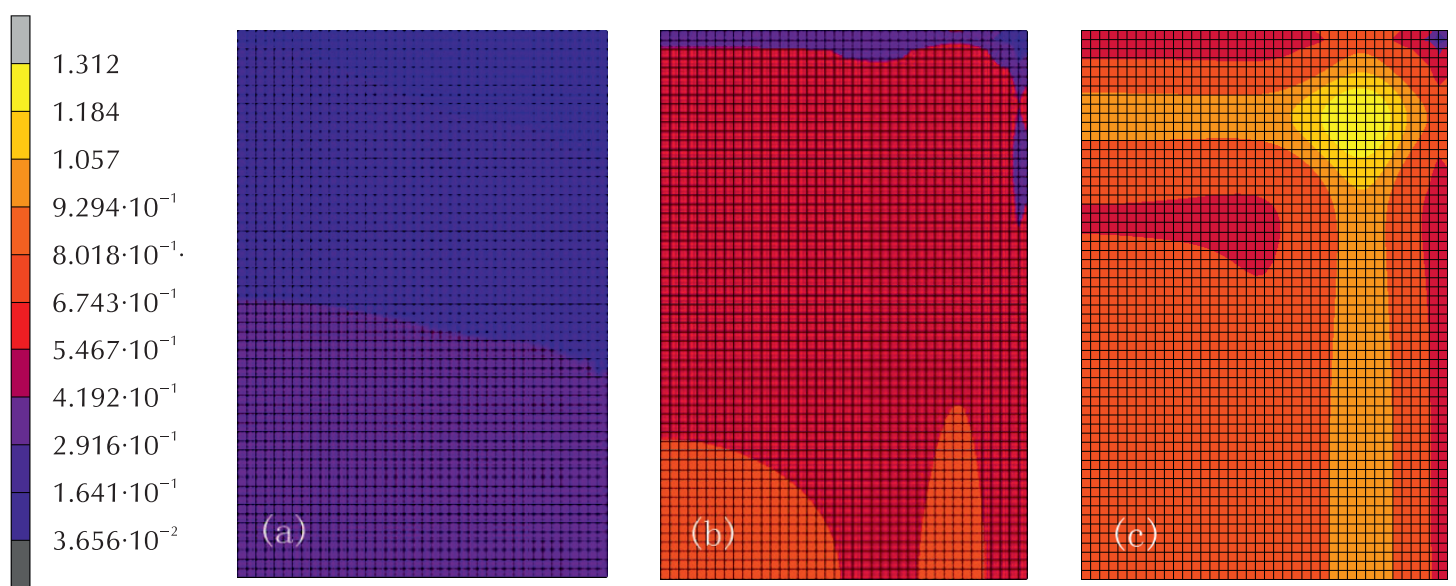

Fig. 6 - Effects of the silicon rubber thickness on the stress in the germanium solar cell: (a) 57,5 $\mu$ m, (b) $115 \mu \mathrm{m}$, (c) $230 \mu \mathrm{m}$

Slika 6 - Utjecaj debljine silikonske guma na naprezanje germanijske solarne ćelije: (a) 57,5 $\mu \mathrm{m}$, (b) $115 \mu \mathrm{m}$, (c) $230 \mu \mathrm{m}$ 

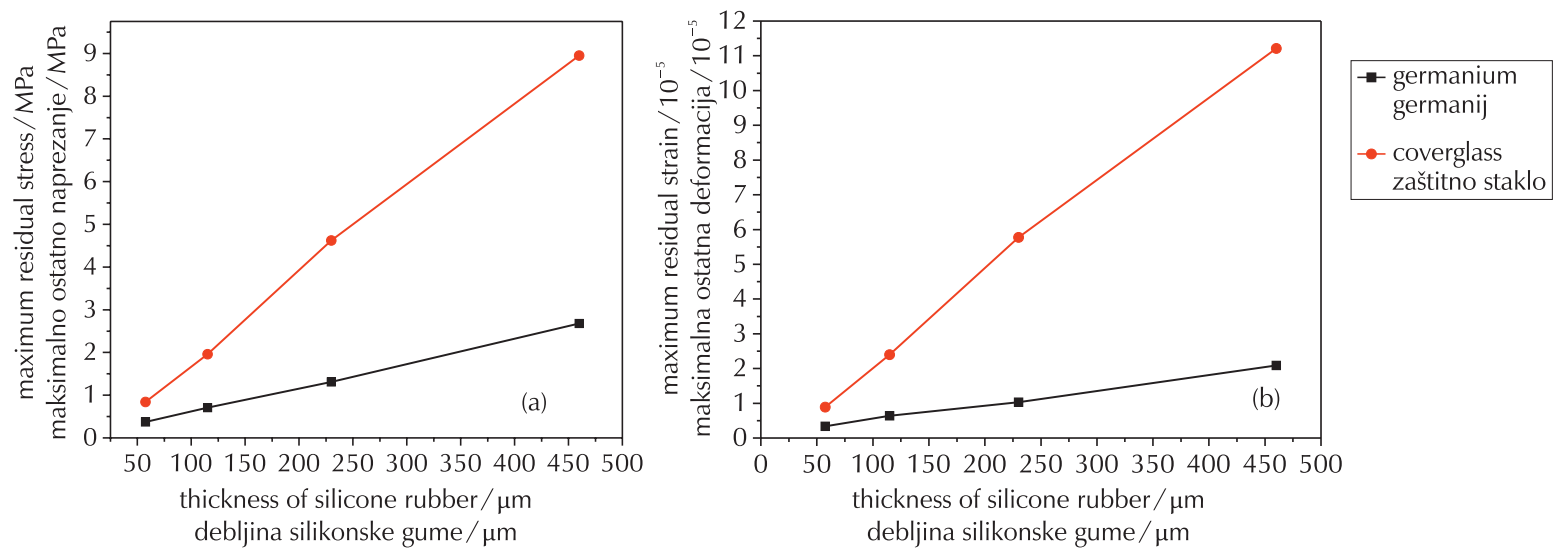

Fig. 7 - Effects of the silicone rubber thickness on the maximum residual stress (a) and maximum residual strain (b) in the solar cell module

Slika 7 - Utjecaj debljine silikonske gume na maksimalno ostatno naprezanje (a) i maksimalnu ostatnu deformaciju (b) u modulu solarne ćelije

The effect of the silicon rubber thickness on the stress distribution of the germanium solar cell is shown in Fig. 6 . According to the above work, the stress in the germanium solar cell is composed of normal stress and tensile stress caused by the silicone rubber volume expansion. With the increase in silicone rubber thickness, normal stress and tensile stress in the germanium solar cell will significantly increase, however, normal stress will increase more significantly than tensile stress. Thus, the concentration area of the stress in the germanium solar cell changes from the centre area to the diagonal area gradually.

As can be observed from Figs. 5-6, the distribution of the residual stress in the germanium solar cell is more uniform than that of the coverglass. With different silicone rubber thicknesses, the maximum stress values in the coverglass are overall larger than that of the germanium solar cell.

The effects of the silicone rubber thickness on the maximum residual stress and maximum residual strain in the coverglass and the germanium solar cell are shown in Fig. 7(a) and Fig. 7(b), respectively. The residual stress of the coverglass increases obviously with the silicone rubber thickness increase, its maximum value increases from $0.370 \mathrm{MPa}$ to $8.951 \mathrm{MPa}$, about 24.2 times. The strain of the coverglass increases from $0.891 \cdot 10^{-5}$ to $11.210 \cdot 10^{-5}$, about 12.6 times when the thickness increases. The residual stress of the germanium solar cell increases obviously with the silicone rubber thickness' increase, its maximum value increases from $0.370 \mathrm{MPa}$ to $2.678 \mathrm{MPa}$, about 7.2 times. It can be observed that the change in the germanium solar cell's strain is similar to that of the stress. It increases from $0.334 \cdot 10^{-5}$ to $2.091 \cdot 10^{-5}$, about 6.3 times when the thickness increases.

\subsection{Effect of curing temperature on the residual stress and strain in solar cell module}

The curing time of the silicone rubber will change obviously with the curing temperature, and will also have a certain influence on the volume change during the curing process. Therefore, the volume change caused by dehydration is ignored when the influence of the curing temperature is investigated, so the thermal stress caused by the temperature change is the only considered factor. The residual stresses in both the coverglass and the germanium solar cell are calculated. Here, the curing temperature takes four values, $40{ }^{\circ} \mathrm{C}, 60^{\circ} \mathrm{C}, 80^{\circ} \mathrm{C}$, and $100{ }^{\circ} \mathrm{C}$, respectively.

The effect of the curing temperature on the stress distribution of the coverglass is shown in Fig. 8. With the increase in curing temperature, the increase in silicone rubber volume and the constraint of the rubber/coverglass interface result in greater strain of the silicone rubber. Therefore, the stress in the coverglass becomes greater. Because the strain concentration location on the rubber/coverglass interface is unchanged with the increase in curing temperature, the stress distribution of the coverglass remains invariant. The stress of the coverglass concentrates in the module boundary area, and the maximum value appears in the corner.

The effect of the curing temperature on the stress distribution of the germanium solar cell is shown in Fig. 9. The tensile stress produced at the fixed displacement position takes up the main part of the germanium solar cell's residual stress. The stress concentrates in the module centre area, and decreases along the $\mathrm{Y}$ axis. The maximum residual stress value appears in the centre. The stress distribution of the germanium solar cell is stable with different curing temperature. 
As can be observed from Figs. 8-9, the stress in the coverglass is larger than that of the germanium solar cell with the same curing temperature. The distribution of the residual stress in the germanium solar cell is more uniform than that of the coverglass. With the increase in curing temperature, the concentration area of the stress and strain in both parts materials is different. Unlike the service process of the solar cell module, the temperature variation range is narrower in the encapsulation process, so the thermal stress caused by the temperature variation is relatively lower.

The effects of the curing temperature on the maximum residual stress and maximum residual strain in the coverglass and germanium solar cell are shown in Fig. 10(a) and
Fig. 10(b), respectively. The residual stress of the coverglass increases obviously with the curing temperature increase, its maximum value increases from $0.235 \mathrm{MPa}$ to $0.535 \mathrm{MPa}$, about 2.2 times. The strain of the coverglass increases from $2.922 \cdot 10^{-6}$ to $7.305 \cdot 10^{-6}$, about 2.5 times when the curing temperature increases within the set range. The residual stress of the germanium solar cell increases noticeably with curing temperature increase, its maximum value increases from $0.094 \mathrm{MPa}$ to $0.214 \mathrm{MPa}$, about 2.2 times. It can be seen that the germanium solar cell strain's change is similar to that of the stress, i.e., it increases from $0.854 \cdot 10^{-6}$ to $2.137 \cdot 10^{-6}$, about 2.5 times when the curing temperature increases.
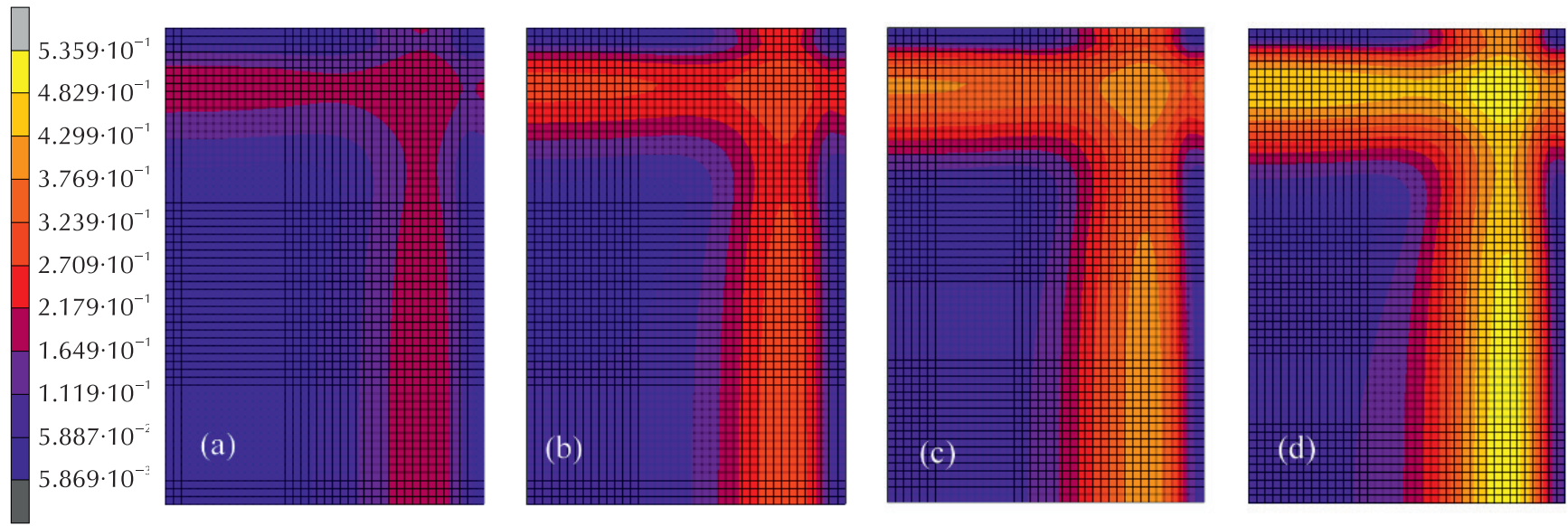

Fig. 8 - Effects of the curing temperature on the stress in the coverglass: (a) $40{ }^{\circ} \mathrm{C}$, (b) $60{ }^{\circ} \mathrm{C}$, (c) $80{ }^{\circ} \mathrm{C},(d) 100{ }^{\circ} \mathrm{C}$ Slika 8 - Utjecaj temperature očvršćivanja na naprezanje zaštitnog stakla: (a) $40{ }^{\circ} \mathrm{C}$, (b) $60{ }^{\circ} \mathrm{C}$, (c) $80{ }^{\circ} \mathrm{C}$, (d) $100{ }^{\circ} \mathrm{C}$
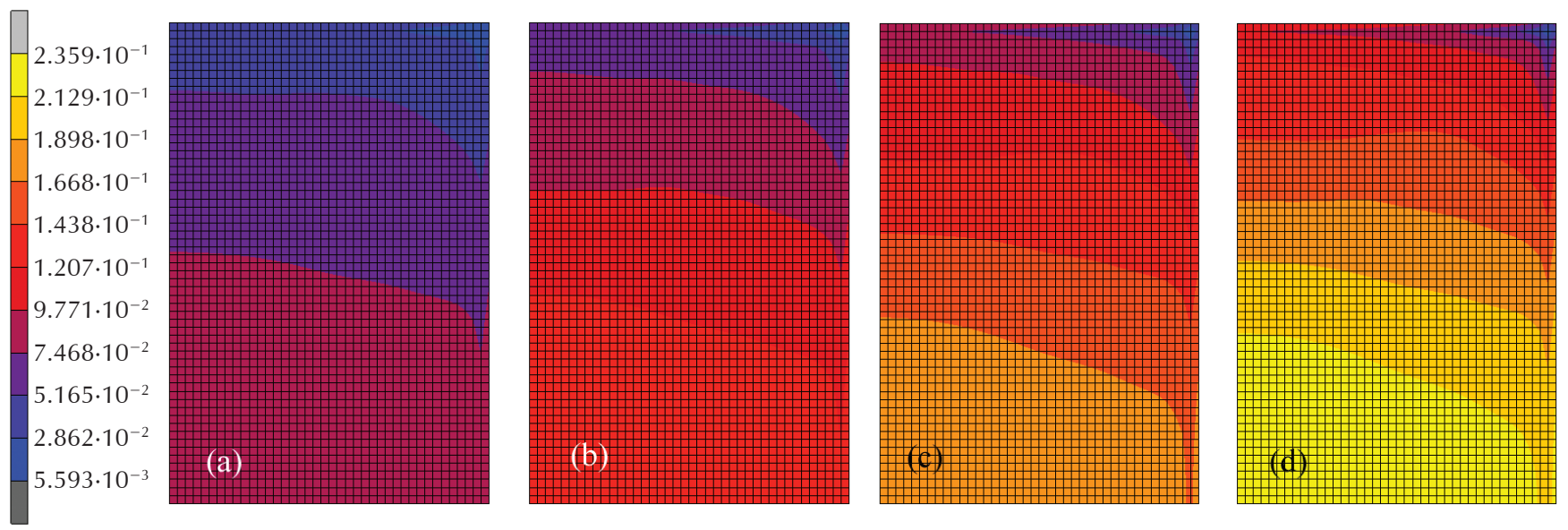

Fig. 9 - Effects of the curing temperature on the stress in the germanium solar cell: (a) $40{ }^{\circ} \mathrm{C}$, (b) $60{ }^{\circ} \mathrm{C}$, (c) $80{ }^{\circ} \mathrm{C}$, (d) $100{ }^{\circ} \mathrm{C}$ Slika 9 - Utjecaj temperature očvršćivanja na naprezanje germanijske solarne ćelije: (a) $40{ }^{\circ} \mathrm{C}$, (b) $60{ }^{\circ} \mathrm{C}$, (c) $80{ }^{\circ} \mathrm{C}$, (d) $100{ }^{\circ} \mathrm{C}$ 

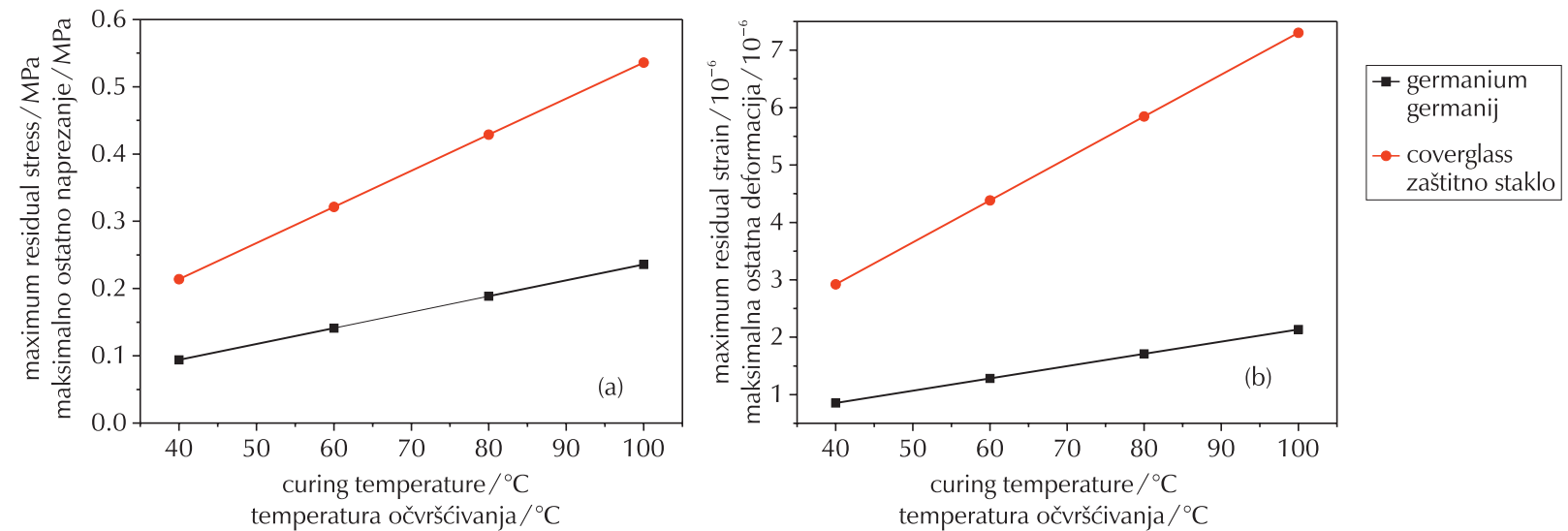

Fig. 10 - Effects of the curing temperature on the maximum residual stress (a) and maximum residual strain (b) in the solar cell module

Slika 10 - Utjecaj temperature očvršćivanja na maksimalno ostatno naprezanje (a) i maksimalnu ostatnu deformaciju (b) u modulu solarne ćelije

\section{Conclusions}

The effects of curing process parameters (elastic modulus and thickness of silicone rubber, and curing temperature) on residual stress in a solar module have been studied with FEM.

(1) The variation of silicone rubber elastic modulus has great impact on residual stress in the solar cell module. When the silicone rubber elastic modulus increases from $0.56 \mathrm{MPa}$ to $14 \mathrm{MPa}$, the residual stress maximum value of the coverglass increases from 0.642 MPa to $5.057 \mathrm{MPa}$, about 7.8 times. Moreover, the stress mainly concentrates in the boundary area of the coverglass. However, when the silicone rubber elastic modulus increases from 0.56 MPa to $14 \mathrm{MPa}$, the residual stress maximum value of the germanium solar cell increases from $0.175 \mathrm{MPa}$ to $2.378 \mathrm{MPa}$, about 13.9 times. Moreover, the stress mainly concentrates in the centre area of the germanium solar cell.

(2) The variation of silicone rubber thickness has significant impact on the residual stress and the distribution of the residual stress in the solar cell module. With an increase in silicone rubber thickness from $57.5 \mu \mathrm{m}$ to $460 \mu \mathrm{m}$, the residual stress maximum value of the coverglass increases from 0.839 MPa to 8.951 MPa, about 10.6 times. Moreover, the stress mainly concentrates in the boundary area of the coverglass. However, with an increase in silicone rubber thickness from $57.5 \mu \mathrm{m}$ to $460 \mu \mathrm{m}$, the residual stress maximum value of the germanium solar cell increases from $0.370 \mathrm{MPa}$ to $2.678 \mathrm{MPa}$, about 7.2 times. Moreover, the concentration area of the stress in the germanium solar cell changes from the centre area to the diagonal area with the thickness increase.

(3) The variation of curing temperature has a minor impact on the residual stress in the solar cell module. With an increase in curing temperature from $40{ }^{\circ} \mathrm{C}$ to $100{ }^{\circ} \mathrm{C}$, the residual stress maximum value of the coverglass increases from 0.235 MPa to 0.535 MPa, about 2.2 times. Moreover, the stress mainly concentrates in the boundary area of the coverglass. With an increase in curing temperature from $40{ }^{\circ} \mathrm{C}$ to $100{ }^{\circ} \mathrm{C}$, the residual stress maximum value of the germanium solar cell increases from 0.094 MPa to $0.214 \mathrm{MPa}$, about 2.2 times. Moreover, the stress mainly concentrates in the centre area of the germanium solar cell.

\section{List of abbreviations and symbols Popis kratica i simbola}

$$
\begin{aligned}
& \text { CAE - computer aided engineering } \\
& \text { - računalno potpomognuto inženjerstvo } \\
& \text { E - - elastic modulus of silicone rubber } \\
& \text { - modul elastičnosti silikonske gume } \\
& \text { FEM - finite element method } \\
& \text { - metoda konačnih elemenata } \\
& \text { G - shear modulus } \\
& \text { - modul smicanja } \\
& u, v, w \quad \text { - relative displacement components } \\
& \text { - komponente relativnog pomaka } \\
& x, y, z \quad-\text { coordinate axes } \\
& \text { - osi koordinatnog sustava } \\
& \begin{array}{llll}
\gamma_{x y} & \gamma_{y z} & \gamma_{x z} & - \text { shear strain components }
\end{array} \\
& \text { - komponente smične deformacije } \\
& \varepsilon_{\mathrm{x}}, \varepsilon_{\mathrm{y},} \varepsilon_{\mathrm{z}} \quad \text { - longitudinal strain components } \\
& \text { - komponente uzdužne deformacije } \\
& v \quad-\text { Poisson's ratio } \\
& \text { - Poissonov omjer } \\
& \sigma_{x}, \sigma_{y \prime} \sigma_{z} \quad-\text { normal stress components } \\
& \text { - komponente okomitog naprezanja } \\
& \sigma_{x y} \sigma_{y z}, \sigma_{z x}-\text { shear stress components } \\
& \text { - komponente smičnog naprezanja }
\end{aligned}
$$




\section{References \\ Literatura}

1. J. P. Yu, G. Q. Yang, X. W. Liang, Modern Small Satellite Technology and Application, Shanghai Popular Science Press, 2004.

2. R. Y. Kim, Dimensional stability of composite in a space thermal environment, Compos. Sci. Technol. 60 (2000) 2601-2608, doi: http://dx.doi.org/10.1016/S02663538(00)00052-X.

3. G. H. Sun, S. L. Yan, G. Chen, Analytical model of thermal stress for Encapsulation and Service Process of Solar Cell Module, Adv. Mater. Res. 97-101 (2010) 2699-2702, doi: http://dx.doi.org/10.4028/www.scientific.net/AMR.97101.2699

4. X. Y. Wang, H. B. Geng, S. Y. He, D. Z. Yang, Thermal stress evolution research of solar cell structure under thermal cycling, Acta Energiae Solaris Sinica 28 (4) (2007) 345-350.

5. M. Weps, K. Naumenko, H. Altenbach, Unsymmetric three-layer laminate with soft core for photovoltaic modules, Compos. Struct. 105 (2013) 332-339, doi: http://dx.doi. org/10.1016/j.compstruct.2013.05.029.

6. L. X. Zhang, S. Q. Yang, S. Y. He, The adhesive properties study of the solar cell cemented structure under vacuum thermal cycling, China Adhes. 11 (4) (2002) 1-3.

7. Y. Gao, Z. J. Li, D. Z. Yang, The impact of vacuum thermal cycling on the mass loss rate and coefficient of linear expansion of the M40J / 5228A composite, Acta Materiae Compositae Sinica 21 (6) (2004) 108-113.
8. V. Brand, K. Levi, M. D. McGehee, Film stresses and electrode buckling in organic solar cells, Sol. Energ. Mat. Sol. C. 103 (2010) 80-85, doi: http://dx.doi.org/10.1016/j.solmat.2012.04.003.

9. P. Y. Yoon, T. H. Baek, H. S. Chung, Numerical simulation of bowing phenomenon in ultra-thin crystalline silicon solar cells, Sol. Energ. Mat. Sol. C. 105 (2014) 705-714, doi: http://dx.doi.org/10.1016/j.solener.2014.04.027.

10. L. X. Zhang, S. Q. Yang, S. Y. He, Proton irradiation damage effects of silicone rubber for spacecraft solar cell, Acta Energiae Solaris Sinica 24 (6) (2003) 851-855.

11. H. Y. Han, H. K. Yoon, C. S. Yoon, Parallel polymer tandem solar cells containing comb-shaped common electrodes, Sol. Energ. Mat. Sol. C. 132 (2015) 56-66, doi: http://dx.doi. org/10.1016/j.solmat.2014.08.018.

12. S. Y. Yan, Z. M. Xie, RTV silicone rubber of space-grade, Silicone Mater. 14 (3) (2000) 3-6.

13. J. Jaruchattada, A. Fuongfuchat, C. Pattamaprom, Rheological Investigation of Cure Kinetics and Adhesive Strength of Polyurethane Acrylate Adhesive, J. Appl. Polym. Sci. 123 (4) (2012) 2344-2350, doi: http://dx.doi.org/10.1002/ app. 34754 .

14. L. Dai, Z. Zhang, Y. Zhao, H. Liu, Z. Hie, Effects of polymeric curing agent modified with silazanes on the mechanical properties of silicone rubber, J. Appl. Polym. Sci. 111 (2) (2009) 1057-1062, doi: http://dx.doi.org/10.1002/app.29063.

15. H. H. Chen, J. Yang, X. X. Xue, New FEM tutorial examples of marc, China Machine Press, 2007. 


\title{
SAŽETAK
}

\section{Utjecaj procesa očvršćivanja na ostatno naprezanje u modulu solarne ćelije}

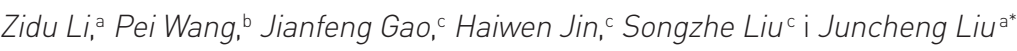

Solarni paneli trebaju biti iznimno pouzdani, a na pouzdanost i životni vijek znatno utječe ostatno naprezanje. Za simulaciju utjecaja parametara izrade četvrtastog solarnog panela, kao što su modul elastičnosti, debljina ljepila i temperatura očvršćivanja, na ostatno naprezanje u solarnom modulu primijenjena je metoda konačnih elemenata.

Rezultati pokazuju da ostatno naprezanje linearno raste s porastom tih triju faktora. Rezidualna deformacija slijedi rezidualno naprezanje. Detaljno su razmatrani mehanizam nastanka i tijek raspodjele naprezanja. Na ostatno naprezanje značajan je utjecaj debljine i modula elastičnosti silikonske gume, no manje je uočljivo djelovanje temperature očvršćivanja.

\section{Ključne riječi}

Modul solarne ćelije, očvršćivanje, ostatno naprezanje, metoda konačnih elemenata, modul elastičnosti

a School of Materials Science and Engineering, Tianjin Polytechnic University, 300387 Tianjin, Kina

${ }^{b}$ Auditing Department, Tianjin Polytechnic University, 300387 Tianjin, Kina

${ }^{c}$ The $18^{\text {th }}$ Research Institute, China Electronics Technology Group Corporation, 300381 Tianjin, Kina
Izvorni znanstveni rad Prispjelo 3. prosinca 2015 Prihvaćeno 28. siječnja 2016. 